\title{
Birinci Basamakta Çalışan Ebe ve Hemşirelerin Obezite Önyargısı
}

\author{
Prejudice Obesity of Midwives and Nurses in the Primary Health Care
}

\author{
Ayten YILMAZ YAVUZ ${ }^{1}$, Hasret YALCINOZ BAYSAL ${ }^{2}{ }^{\circ}$ \\ ${ }^{1}$ Recep Tayyip Erdoğan University School of Health Department of Public Health Nursing, Rize, Turkey \\ 2 Ataturk University Faculty of Nursing Department of Public Health Nursing, Erzurum, Turkey
}

ÖZ

\begin{abstract}
Amaç: $\mathrm{Bu}$ çalı̧̧mada, birinci basamak sağlık hizmeti veren kuruluşlarda çalışan ebe ve hemşirelerin obezite önyargısının belirlenmesi amaçlanmıştır.

Yöntem: Tanımlayıcı türdeki bu araştırmanın evrenini Türkiye'nin doğusunda bulunan iki ildeki birinci basamakta hizmet veren 287 ebe ve hemşire oluşturmuştur. Araştırmada örneklem seçimine gidilmedi. Araştırmaya katılmayı kabul eden ve aktif olarak birinci basamakta çalışan 229 ebe ve hemşire araştırmanın örneklemini oluşturmuştur. Anket formu, tanımlayıcı özellikler formu ve Obezite Önyargı Ölçeğinden oluşmaktadır. Araştırmanın verileri, SPSS paket programı ile tanımlayıcı istatistikler, $\mathrm{t}$ testi, ANOVA testi ve korelasyon testi kullanılarak değerlendirildi. Araştırmaya başlamadan önce, araşsırmanın yürütüldüğü kurumdan yazılı izin ve Etik Kurul onayı alınmış ve gönüllülük ilkesine dikkat edilmiştir.

Bulgular: Araşıırmadaki katılımcıların obezite önyargı ölçeği puan ortalamaları ile tanıtıcı özellikler arasında istatistiksel olarak önemli bir fark olmadığı belirlendi ( $p>0.05$ ). Araştırmada sağlık personellerinin obezite önyargı ölçeği puan ortalaması $78,57 \pm 11,31$ olup, $\% 56,3$ 'ünün önyargıya eğilimli olduğu, $\% 27,5$ 'inin ise önyargılı olduğu belirlenmiştir.

Sonuç: Birinci basamak sağlık hizmet veren kuruluşlarda çalışan ebe ve hemşirelerin yarısından fazlasının obez bireylere karşı önyargıya eğilimli olduğu bulunmuştur. Bu sonuç eğitim müdahalelerinin bir gereklilik olduğunu göstermektedir. Bu sonuçlar doğrultusunda hizmet vermekte olan sağlı personeline bu konuda hizmetiçi eğitimlerinde yer verilmesi önerilebilir.
\end{abstract}

Anahtar Kelimeler: Sağlık profesyoneli, Obezite, Önyargı.

\section{ABSTRACT}

Objective: This study aims to determine the obesity prejudice of midwives and nurses working in institutions providing primary health care service.

Methods: This descriptive study the universe's species, the two provinces located east of Turkey has created 287 midwives and nurses serving in primary care. The sample of the study was not chosen. 229 midwives and nurses who accepted to participate and who were working actively in primary health care constitutes the sample of the study. The questionnaire form consists of descriptive characteristics form and Obesity Prejudice Scale. The data of the study were assessed with SPSS package program by using descriptive statistics, $t$ test, ANOVA test and correlation test. Before starting the research, written consent and Ethical Board approval were taken from the institution the study was conducted in. Care was taken for the participation to occur on a voluntary basis.

Results: No statistically significant difference was found between the obesity prejudice scale average scores of the participants and their descriptive characteristics $(\mathrm{p}>0.05)$. In the study, the obesity prejudice scale average score of the health personnel was found as $78.57 \pm 11.31$ and $56.3 \%$ were found to be inclined to prejudice, while $27.5 \%$ were found to have prejudice.

Conclusion: It was found that more than half of the midwives and nurses working in institutions providing primary health care were inclined to have prejudice against obese individuals. This result shows that training interventions are a necessity. In line with these results, it can be recommended to train the health personnel providing service about this issue. According to these results; it may be suggested that healthcare personnel providing service take part in in-service training on this subject will be examined.

Key words: Health Professional, Obesity, Obesity Bias.

Corresponding Author: Ayten YILMAZ YAVUZ

Recep Tayyip Erdoğan University School of Health Department of Public Health Nursing, Rize, TURKEY

ayten.yilmaz@erdogan.edu.tr

Received: 23.01.2020 - Accepted: 20.04.2020 


\section{INTRODUCTION}

Obesity is among the most important health problems of our time and its prevalence is increasing gradually (1). According to 2016 data of World Health Organization (WHO), there are more than 1.9 billion overweight individuals, while there are more than 650 million obese individuals. The rate of obesity has been reported to increase almost three times globally from 1975 to 2016 (2). In studies conducted in Turkey, it has been reported that $30 \%$ of individuals are obese and the prevalence of obesity has been reported to increase $44 \%$ in the last 12 years (3-4). In addition to causing a great number of diseases, obesity increases mortality rate. In obese individuals, muscoskeletal system diseases, physical diseases such as osteoarthritis, dyspnea, hypertension, some kinds of cancer and post-operative complications are more common (5-6).

Besides its physiological effects, obesity also causes individuals to be exposed to situations such as prejudice, stigma and discrimination (6). Today, showing obese individuals in social environments as careless, uncompetitive, lazy, undisciplined and as people who are difficult to compromise with results in prejudice against these individuals (7). Negative prejudice and stigma that obese individuals are exposed to are a problem in terms of the kind and quality of health service presentation.

Negative attitude of health personnel causes obese individuals to withdraw themselves from treatment, to have decreased confidence against health personnel and to cancel or postpone appointments more frequently (8-9). Studies have found that students in the field of health and university students (10-15) and health professionals are prejudiced or inclined to be prejudiced against obese individuals (16) and this situation causes individuals to withdraw themselves from treatment and to get insufficient treatment (17).

Today, it is important to know the obesity prejudice in the primary health care system. Addressing obesity prejudice can provide a better understanding of how to provide medical care to obese patients. As primary-level staff, our goal should be to see each patient as a unique individual and to address their unique health needs, rather than letting our negative beliefs and attitudes about obesity guide our personal experiences and practices (18). Therefore, it is important to know the obesity prejudice of midwives and nurses serving the community in primary health care.

The purpose of this study is to find out the obesity prejudice of midwives and nurses working in primary health care institutions.

Research questions:

1. Does the obesity bias scale mean change according to the descriptive characteristics?

2. What is the obesity bias of midwives and nurses working in primary care?

\section{MATERIALS AND METHOD}

\section{Study Design}

The universe of this descriptive study was conducted in two provinces located in the east of Turkey. These two provinces were chosen among the provinces with similar culture to reach more participants. The study consists of 287 midwives and nurses working at primary health care institutions in the aforementioned cities between October 2017 and December 2017. The sample of the study was not chosen and 229 midwives and nurses who accepted to 
participate and who were working actively in primary health care constituted the sample of the study. A total of 58 people were excluded because 12 nurses and 29 midwives did not agree to participate and 17 midwives and nurses were on leave.

\section{Data collection}

The data were collected by the researchers through face to face interview method with a questionnaire form in a period of 10-15 minutes.

\section{Instruments}

The questionnaire form consists of descriptive characteristics form and GAMS-27 Obesity Prejudice Scale.

Descriptive characteristics form: This is a socio-demographic form including 12 questions formed by the researchers. The form has question about the age, gender, marital status, monthly income, educational status, years in the professions, height and weight of the midwives/nurses and also questions about how they defined their body structure, their attitudes against obese individuals and whether there were obese individuals in their families.

Obesity Prejudice Scale: It was developed in 2015 by Ercan et al. in order to measure the obesity prejudice of students receiving health education (19). The scale has 27 items and it was developed in parallel with 5 Likert type. Negative items $(1,3,5,6,8,9,12,13,16,18,19,21,23,24,26)$ are scored from 1 to 5 starting from "totally agree", while positive items $(2,4,7,10,11,14,15,17,20,22,25,27)$ are scored from 5 to 1 starting from "totally agree". The lowest score one can get from the scale is 27 , while the highest score is 135. When the cut-off points of the scale are assessed, scores less than 68.00 are assessed as unprejudice, 68.01-84.99 are assessed as inclined to prejudice and scores higher than 85 are assessed as prejudiced. Cronbach $\alpha$ coefficient of the scale is 0.85 , which proves that it has high reliability (19). In the present study, Cronbach $\alpha$ coefficient was found as 0.81 .

\section{Data analysis}

The data of the study were assessed with SPSS package programming. KolmogorovSmirnov test was used to find out whether the data were normally distributed. Descriptive statistics, $t$ test, ANOVA test and Pearson correlation analyses were used in the study to find out the participants' descriptive characteristics and the association of these with obesity prejudice and $\mathrm{p}<0.05$ was considered as statistical significance level.

\section{Ethical consideration of the study}

Before starting the study, written permission from the institution the study was conducted in and approval was taken from Non-invasive Clinical Researches Ethical Board (Decision Number:40465587-149). In addition, the participants were informed about the research and stated that information of the individuals would be protected and volunteers were included in the study. 


\section{RESULTS}

The average age of the participants was $32.99 \pm 8.10,97.8 \%$ were female, $68.6 \%$ were married, 59.4\% had equal income and expenditure and 37.1\% had associate degree. $54.6 \%$ of the participants were midwives and they had been working for an average of 9.14 \pm 9.07 years. When the factors related with obesity were examined, BMI was found to be $25.24 \pm 4.63 \mathrm{~kg} / \mathrm{m} 2$, $53.3 \%$ were found to have normal weight and $46.3 \%$ were found to consider themselves to have normal weight. When the participants' attitudes for obese individuals were examined, $76.9 \%$ stated that they considered themselves as unprejudiced and $59.0 \%$ stated that there were no obese people in their family (Table 1).

Table 1. Distribution of The Participants in Terms of Descriptive Statistics and Comparison of The Characteristics With Obesity Prejudice Scale $(n=229)$

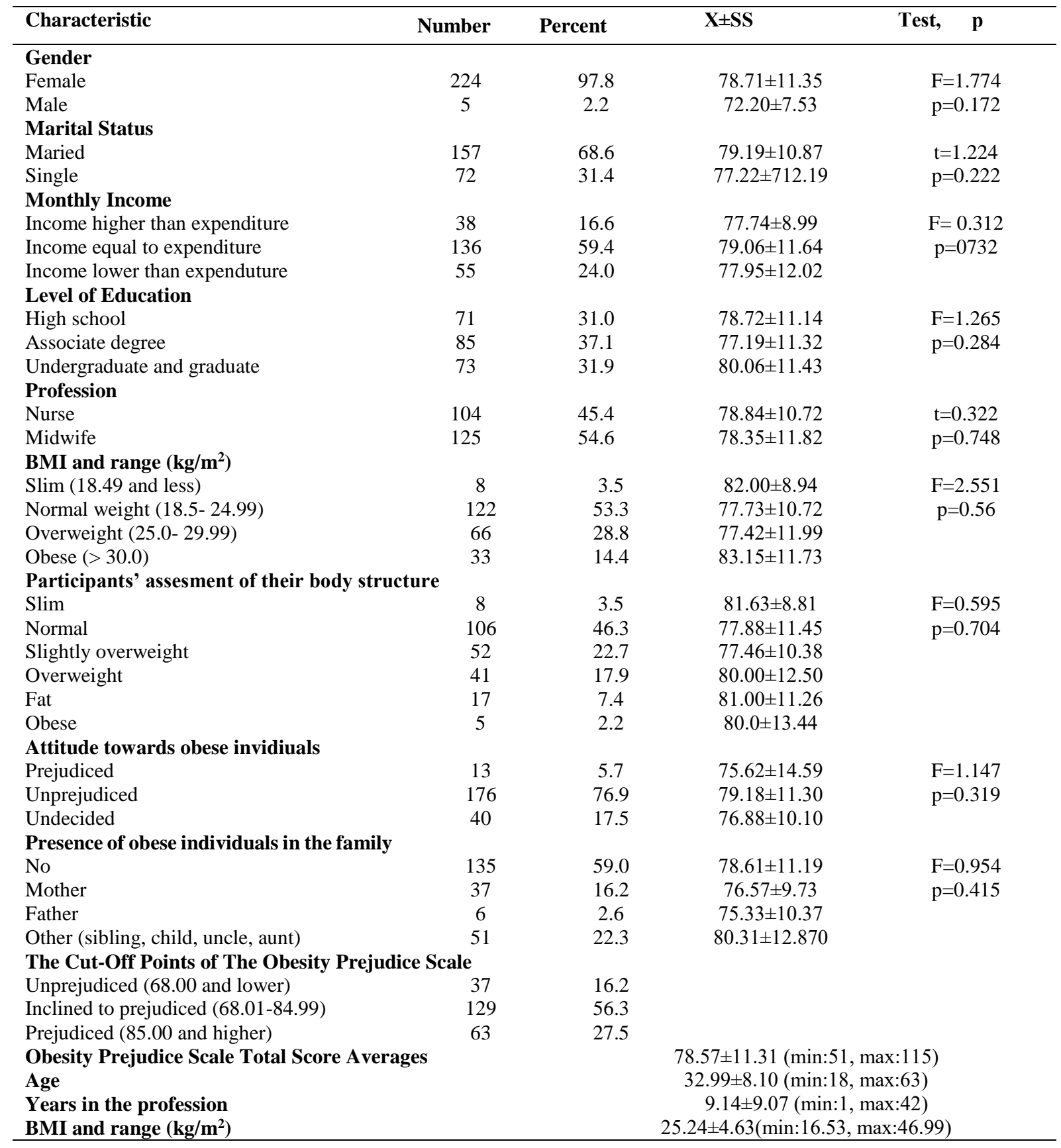


In this study, the average obesity prejudice score of the participants was found as $78.57 \pm 11.31$ (min:51, max:115) (Table 1). When the descriptive characteristics and obesity prejudice scale average scores were compared, no statistically significant difference was found between obesity prejudice scale average scores and midwives' and nurses' gender, marital status, level of income, level of education, profession, how they perceived their weight, their attitudes towards obese individuals and the presence of obese individuals in the family ( $>0.05$ ). When the participants' scores were analyzed in terms of the cut-off points of the obesity prejudice scale, $56.3 \%$ were found to be inclined to prejudice, $16.2 \%$ were found to be unprejudiced and $27.5 \%$ were found to be prejudiced (Table 1).

When the association between obesity prejudice scale total score and age, height, weight, BMI and years in the profession was examined, no statistically significant association was found ( $p>0.05)$ (Table 2).

Table 2. Analysis Of The Association Between Obesity Prejudice Score and Age, Height, Weight, BMI and Years in The Profession

\begin{tabular}{lcccccc}
\hline & & Age & Height & Weight & BMI & Years in the profession \\
\hline Obesity Prejudice Scale total score & $\mathrm{r}$ & 0.105 & 0.027 & 0.111 & 0.101 & 0.067 \\
& $\mathrm{p}$ & 0.115 & 0.689 & 0.094 & 0.126 & 0.314 \\
\hline
\end{tabular}

\section{DISCUSSION}

It was found that nurses and midwives working in institutions which provide primary health care services are inclined to be prejudiced obese individuals. Health personnel's' prejudice and negative attitudes against obese individuals are an undesired picture that can influence individuals' receiving health service. It can be seen as an important problem especially in institutions providing primary care health services.

No statistically significant difference was found between health personnel's' obesity prejudice scale average score and age, gender, marital status, income, level of education, profession, BMI and years in profession (Table 1, Tablo 2). Similarly, no association was found between age and obesity prejudice scale average scores in studies conducted $(10,12)$. Contrary to our study, in a study conducted on primary healthcare professionals, those with more years of employment in the profession were found to be more biased towards obese people (18). Considering that the experience increases with age, this suggests that prejudiced obese in individuals is independent of age and can occur at any age. This result brings to mind that prejudiced obese occurs independently from age in individuals and that it can occur at any age. Unlike the results of our study, Usta et al. 2015 and Soto et al. 2014, have found that women have more prejudice, while some others report that men have more prejudice $(13,15)$. Sert et al. 2006, studies have found similar to our results, which gender does not influence obesity prejudice (10). This result may have occurred due to different sample groups in studies.

In our study, it was found that obesity prejudice scale average score of midwives and nurses working in institutions providing primary health care was $78.57 \pm 11.31$ and that the majority of these midwives and nurses were inclined to be prejudiced against obese individuals (Table1).

In the study of Puhl et al. (2014), 29\% of health professionals treating their eating disorders had negative attitudes towards obese patients (24). In parallel with the results of our study, health personnel were found to be prejudiced against obese individuals in a great number 
of studies. In studies which examined the obesity prejudice levels of health personnel, it was found that $40 \%$ of doctors had negative attitude and $52 \%$ of nurses were reluctant to provide service to obese individuals (21-22). In a study, it was found that some nurses believe that obesity patients lack self-control and are less successful, they consider working with obesity patients as physically exhausting and stressful and prefer not to care about these patients (25).

Obesity is an important public health problem and especially the perspective of health personnel is important. Having a prejudice towards obesity may adversely affect the quality of health care to be provided. This situation also causes reluctance for obese patients to receive health care (26). Obese individuals do not want to apply to primary health care institutions, which means that these individuals are deprived of preventive, outpatient and health care services aimed at protecting and improving health. In these organizations that attach importance to the principle of equal service, this is not a desired situation.

Prejudice scores of the health personnel who stated that they were not prejudiced against obese individuals were found to be higher, although not statistically significant. That is, the health personnel who did not consider themselves as prejudiced against obese individuals were in fact more prejudiced than others. Similarly, in another study, it was found that the individuals who stated that they were unprejudiced against obese individuals were found to have higher obesity prejudice average scores than the individuals who stated that they were prejudiced (12). The reason why individuals had higher average scores although they stated that they were unprejudiced brings to mind that health personnel can have implicit (latent) prejudice that they are not aware of. Our study results and other research results have shown that healthcare personnel may have a bias towards obesity. It can be thought that increasing health personnel's' awareness about their implicit prejudice can be useful in decreasing negative attitude.

When the active role of health personnel in preventing and managing obesity is considered, health professionals should be aware that they are prejudiced and they should get support to be able to overcome this prejudice. In addition, when it is considered that nurses' and midwives' duty is to provide health service by being compassionate, honoured and nonjudgemental, fulfilling this duty is an important issue in terms of increasing the quality of service and increasing the satisfaction of those who are receiving service (24). This research is valuable in creating hypotheses for future research

\section{CONCLUSION}

It was determined that the majority of the midwives and nurses $(56.3 \%)$ working in primary health care institutions were prone to bias against obese individuals and $27.5 \%$ were biased. It is important to ensure that healthcare professionals are aware of whether they are biased in order to provide professional services to obese individuals. In addition, existing prejudices against obese individuals should be reduced. This result shows that training interventions for healthcare professionals are a necessity. In line with these results, it may be suggested that health personnel should be given trainings to reduce obesity bias in in-service trainings and should include respect for obese individuals in these trainings. 


\section{Limitations}

The small sample size in this study is a limitation of the research done in primary care and the failure to realize the comparison group only two provinces in eastern Turkey. The research results in question can only be generalized to the sample group in the current research.

\section{Ethical consideration of the study}

Before starting the study, written permission from the institution the study was conducted in and approval was taken from Non-invasive Clinical Researches Ethical Board (Decision Number:40465587-149). In addition, the participants were informed about the research and stated that information of the individuals would be protected and volunteers were included in the study.

\section{REFERENCES}

1. Bagriacik, N. (2009). National obesity prevention and treatment guide, İstanbul: Obesity Research Association Publications.

2. World Health Organization. Obesity and overweight fact sheet. http://www.who.int/mediacentre/factsheets/fs311/en/. (Access Date: January 1, 2018).

3. Bagriacik, N., Onat, H., Ilhan, B., Tarakc1, T., Ozar, Z., Ozyazar, M. et al. (2009). Obesity profile in Turkey. Int J Diabetes \& Metabolism, 17, 5-8.

4. TURDEP Çalışma grubu TURDEP-II Sonuçlarının Özeti 2010 http://istanbultip.istanbul.edu.tr/wpcontent/uploads/attachments/021_turdep.2.sonuclar inin.aklamasi.pdf. (Access Date: January 1, 2018).

5. Fontaine, K. R., \& Barofsky, I. (2001). Obesity and health-related quality of life. Obes Rev, 2, 173-182.

6. Paker, M. (2017). Psychological bias and discrimination. Cayır, K. \& Ceyhan M.A. (eds). Discrimination: multidimensional approaches. 1th ed. (ss. 41-43). Istanbul; Istanbul Bilgi University Press.

7. Field, A. E., Bamoya, J., \& Colditz, A. (2003). Effects of obesity on epidemiology, health and economy. Wadden, T. A., \& Stunkard, J. A. (eds). Obesity treatment manual, 1 th ed. İstanbul.

8. Gudzune, K. A., Beach, M. C., Roter, D. L., \& Cooper, L. A. (2013). Physicians build less rapport with obese patients. Obesity (Silver Spring), 21(10), 2146-2152.

9. Gudzune, K. A., Bennett, W. L., Cooper, L. A., \& Bleich, S. N. (2014). Patients who feel judged about their weight have lower trust in their primary care providers. Patient Educ Couns, 97(1), 128-131.

10. Sert, H., Seven, A., Çetinkaya, S., Pelin, M., \& Aygin, D. (2006). Evaluation of prejudice against obesity in health high school students. Online Türk Sağlık Bilimleri Dergisi, 4, 9-17.

11. Altınayak, S. Ö., Gur, E. Y., Apay, S.E., \& Ozkan, H. (2017). Midwifery students' prejudice against obese pregnant women. Journal of Anatolia Nursing and Health Sciences, 20(3), 201-207.

12. Yildiz, M., \& Yalcinoz Baysal, H. (2019). Prejudice against obesity in university students studying in health-related departments. Perspect Psychiatr Care, 55 (2): 170174. 
13. Soto, L., Armendariz-Anguiano A. L., Bacardi-Gascon, M., \& Cruz, A. J. (2014). Beliefs, attitudes and phobias among Mexican medical and psychology students towards people with obesity. Nutr Hosp, 30(1), 37-41.

14. Altun, S. (2015). Determination of university students' prejudice against obesity. Baskent University, Faculty of Health Sciences. Nutrition and Dietetics, Ankara.

15. Usta, E., Acar, K., \& Aygin, D. (2015). The attitudes of students towards obesity in the vocational college of health services. Electronic Journal of Vocational Colleges, Special 1ssue: 46-53.

16. Schwartz, M. B., O'Neal, H., Brownell, K. D., Blair, S., \& Billington, C. (2003). Weight bias among health professionals specializing in obesity. Obes Res, 11, 10331039.

17. Puhl, R. M., \& Brownell, K. D. (2003). Ways of coping with obesity stigma: review and conceptual analysis. Eat Behav. 4, 53-78.

18. Khandalavala, B. N., Rojanala, A., Geske, J. A., Koran-Scholl, J. B., Guck, T. P. (2014). Obesity Bias in Primary Care Providers. Fam Med, 46(7), 532-535.

19. Ercan, A., Akçil Ok, M., \& Kızıltan, G. (2015). Development of obesity prejudice scale for students of health sciences: GAMS 27- obesity prejudice scale. International PeerReviewed Journal of Nutrition Research, 3(2), 29-43.

20. Perez-Lopez, M. S., Lewis, R. J., \& Cash, T. F. (2015). The relationship of antifat attitudes to other prejudicial and gender-related attitudes. Journal of Applied Social Psychology, 24(5), 517-525.

21. Usta, E., \& Akyolcu, N. (2014). The evaluation of surgical nurses' knowledge and applications on the care of overweight/ obese people. Florance Nightingale Nursing Journal, 22, 1-7.

22. Jay, M., Kalet, A., Ark, T., McMacken, M., Messito M. J., Richter R., et al. (2009). Physicians' attitudes about obesity and their associations with competency and specialty: a cross-sectional study. BMC Health Serv Res, 24(9), 1-11.

23. Danielsdottir, S., O’Brien, K. S., \& Ciao, A. (2010). Anti-fat prejudice reduction: a review of published studies. Obesity Facts, 3, 47-58.

24. Puhl, R. M., Latner, J. D., King, K. M., \& Luedicke J. (2014). Weight bias among professionals treating eating disorders: attitudes about treatment and perceived patient outcomes. International Journal of Eating Disorders, 47(1), 65-75.

25. Phelan, S. M., Burgess, D. J., Yeazel, M. W., Hellerstedt, W. L., Griffin, J. M., \& van Ryn M. (2015). Impact of weight bias and stigma on quality of care and outcomes for patients with obesity. Obes Rev., 16(4), 319-326.

26. Forhan, M., \& Salas, X. R. (2013). Inequities in healthcare: a review of bias and discrimination in obesity treatment. Can J Diabetes, 37(3), 205-209. 